\title{
ポリマーブレンドにおける成分間の相互作用 Specific Interaction between Components in Polymer Blend
}

\section{1.はじめに}

ポリマーブレンドに関して毎年膨大な報告が出されてい る。著者らも一連の研究 ${ }^{1 \sim 5)}$ を行っておうり, 既報 ${ }^{4)}$ では, ポリマーブレンドの相溶性を考える場合の指標として用いら れている溶解度パラメータ (Solubility parameter, SP) ${ }^{6)}$ と, 実際の相溶性が一致しない場合があることを指摘した。 では，相溶性を支配する真の因子は何かについて考えない といけない。また，非相溶系ブレンドにおける成分の分散 性は, 溶融混練前の予備混合法で大きく变わることも明ら

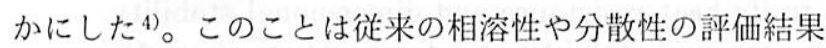
あ，個々の作製条件を前提に考える必要があることを意味 している。本稿では，このようなポリマーブレンドの研究 の現状と問題点について解説したい。ただし，膨大な文献 のすべてを著者が目を通しているのではないことをはじめ にお断りしておく。

\section{2. そもそも SP 值とは？}

成分間の SP 值の差が小さいと相溶性が高く，大きいと 非相溶系ブレンドになる。非相溶系の場合, 1 成分が連続 相（マトリックス, 海）を形成し, 他成分が島状の分散相 （ドメイン）を形成することが多く，ドメインサイズむ SP 值に依存するとされている。

表 1 には，いくつかのポリマーの SP 值を示した ${ }^{7)}$ 。ブ レンド系の相溶性は，ポリメタクリル酸メチル (PMMA)/ ポリ酢酸ビニル（PVAc）系は非相溶, ポリ塩化ビニル (PVC)/PVAc 系は部分相溶, PVC/PMMA 系は相溶で $\mathrm{SP}$ 值の差と一致していない8)。また，この表でもっとも

\footnotetext{
* 大阪工業大学工学部応用化学科

大阪工業大学ナノ材料マイクロデバイス研究センター

大阪市旭区大宮 5-16-1 个 535-8585

Department of Applied Chemistry and Nanomaterials

Microdevices Research Center, Osaka Institute of Technology

5-16-1, Ohmiya, Asahi-ku, Osaka, 535-8585 Japan
}

中村吉伸*

Yoshinobu NAKAMURA
表 1 いくつかのポリマーの SP 值

\begin{tabular}{lc}
\hline \multicolumn{1}{c}{ ポリマー } & SP 值/(MPa) \\
\hline ポリメタクリル酸メチル (PMMA) & 19.0 \\
ポリ酢酸ビニル (PVAc) & 19.2 \\
ポリ塩化ビニル (PVC) & 19.6 \\
ポリビニルアルコール (PVA) & 25.8 \\
\hline
\end{tabular}

$\mathrm{SP}$ 值の差が大きい PMMA/ポリビニルアルコール（PVA） 系はPVAのケン化度によっては相溶系に限りなく近づく こと（SEM でドメインが観察されない）を既報 ${ }^{5)}$ で明ら かにした。

では,そもそも SP とは何か。SP は有機溶剤の分子間 力を表している。 SP の大きなむのは分子間引力が強いの で, SPの小さな分子はその中に入り込めない, つまり “似たもの同士”のみ溶解できることを示す指標で, SP は以下のように定義されている ${ }^{9)} 。$

液体の分子間力, つまり凝集力はその液体の蒸発エンタ ルピー $\Delta H_{\mathrm{v}}$ に依存する。 $\Delta H_{\mathrm{v}}$ は, 液体の分子間力に打ち 勝って気体になるのに必要なエネルギーである。液体 $1 \mathrm{~cm}^{3}$ あたりの凝集力を凝集エネルギー密度 (Cohesive energy density, CED）と定義され， $\Delta H_{\mathrm{v}}$ と次式の関係がある。

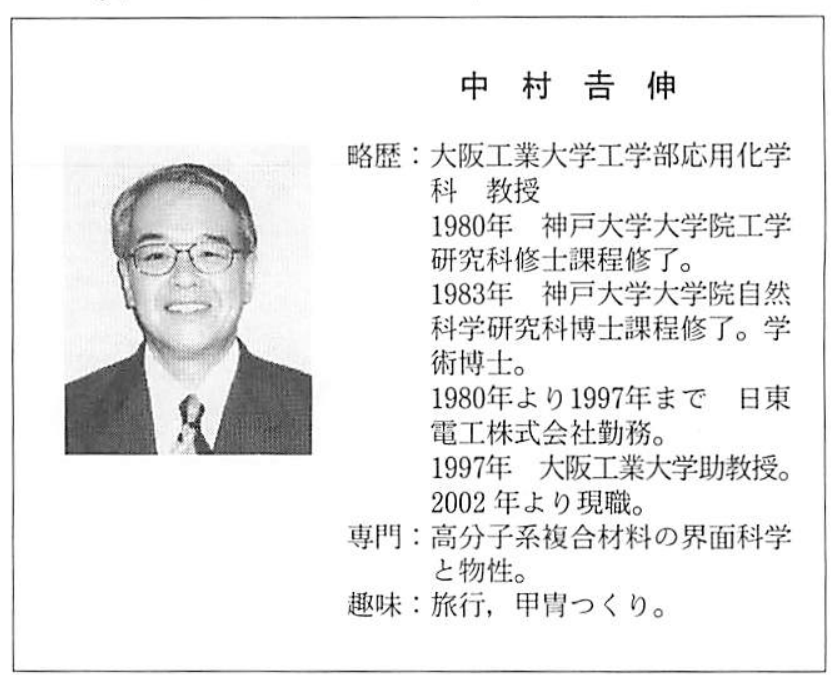




$$
\mathrm{CED}=\frac{\Delta H_{\mathrm{v}}-R T}{\nu}
$$

$\Delta H_{\mathrm{v}}-R T$ は, $\Delta H_{\mathrm{v}}$ から蒸発に必要な仕事を差し引いて内

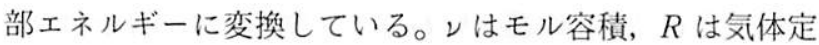
数， $T$ は温度である。SI 単位で $\mathrm{Jm}^{-3}$ になる。 $\mathrm{SP}$ は次式 のように定義される。

$$
\mathrm{SP}=\sqrt{\mathrm{CED}}
$$

単位は $\left(\mathrm{Jm}^{-3}\right)^{1 / 2}$ だが，一般に $(\mathrm{MPa})^{1 / 2}$ で示されるこ とが多い。

一方, 2 種の有機溶剤の混合を熱力学で考えると次式の ようになる。

$$
\Delta G_{\mathrm{m}}=\Delta H_{\mathrm{m}}-T \Delta S_{\mathrm{m}}
$$

ここで $\Delta G_{\mathrm{m}}$ は混合による Gibbs の自由エネルギー変化, $\Delta H_{\mathrm{m}}$ は混合によるエンタルピー変化, $\Delta S_{\mathrm{m}}$ は混合による エントロピー変化であり, $\Delta G_{\mathrm{m}}<0$ の場合は混ざり合う。 Hildebrand ${ }^{6)}$ は, $\Delta H_{\mathrm{m}}, \Delta S_{\mathrm{m}}$ を以下のように表している。

$$
\begin{aligned}
& \Delta H_{\mathrm{m}}=V\left(\delta_{1}-\delta_{2}\right)^{2} \phi_{1} \phi_{2} \\
& \Delta S_{\mathrm{m}}=-R\left(n_{1} \ln x_{1}+n_{2} \ln x_{2}\right)
\end{aligned}
$$

ここで $V$ は混合系のモルあたりの体積， $\phi$ は容積分率， $\delta$ はSP， $x$ はモル分率， 1,2 は有機溶刘の種類を示す。

以上の低分子における考え方は, Flory ${ }^{10)}$ や Huggins ${ }^{11}$ により高分子に拡張された。相溶性が高いのは $\delta_{1}=\delta_{2}$ のときである。高分子には蒸発がないので, Small ${ }^{12)}$ や Fedors ${ }^{13)}$ が SP 值の算出方法を提案している。

ここで(3) 式の $\Delta H_{\mathrm{m}}$ に着目すると理想溶液では $\Delta H_{\mathrm{m}}=0$ であるが, 実在系で混合する溶剤間あるいはポリマー間の 分子間力が単独のそれより強い場合は, マイナスになる。 これに対して SP 值は, 上述のように溶剤やポリマー単独 の分子間力のみに基づいているので, (4) 式の $\Delta H_{\mathrm{m}}$ がマ イナスになることはない。つまり，ポリマーブレンドにお ける相溶性が SP 值からの予測と異なることがあるのは当 然であり，これに影響しているのが成分間の相互作用であ る。SP 值はあくまで目安と考えるべきである。

\section{PVC/PMMA ブレンドは相溶系か？}

相溶系と報告されているものを以下にあげた。PMMA

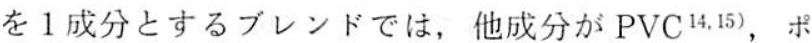
リビニルピロリドン (PVP) ${ }^{16)}$ ，ポリビニルフェノール $(\mathrm{PVPh})^{17)}$ ，フェノールノボラック樹脂 ${ }^{18)}$ ，ポリエチレン オキサイド (PEO) ${ }^{19)}$ の場合が相溶である。PVPを 1 成 分とするブレンドで上記以外では, 他成分が $\mathrm{PVA}^{20)}$, 酢 酸ビニルービニルアルコール共重合体 ${ }^{21)}$, ポリメタクリ ル酸 ${ }^{22)}, \mathrm{PVPh}^{23.24)}$ ，ポリエチレングリコール ${ }^{25)}$ の場合 が相溶である。また，フェノール樹脂/ポリ $\varepsilon$ ーカプロラク トン ${ }^{26)}, \mathrm{PVPh} /$ ポリトリメチレンテレフタレート ${ }^{27)}$ む相 溶と報告されている。これらの相溶性は成分間の相互作用
の効果であり，これを水素結合としているものが多い。成 分ポリマーの官能基が，プロトン供与体と受容体を含む組

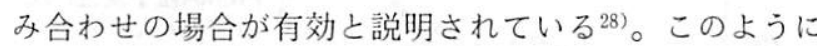
$\mathrm{SP}$ 値より成分間相互作用が大きく寄与している。

ところで, 前項で述べたいくつかの汎用ポリマー（表 1) のブレンド系の相溶性は, 著者ら ${ }^{8)}$ が溶融混練によって, つまり同一条件で作製し，動的粘弾性と SEM 観察で確認 したものである。PVC/PMMA ブレンドは，典型的な相 溶系とされているが，非相溶系とした文献もある。これは 作製条件で異なるためで，溶剤キャストの場合，ジメチル ホルムアミド (DMF) では相溶である ${ }^{14)}$ が, メチルエチ ルケトン F やテトラヒドロフラン溶液では非相溶で, 後 者の方がより不均一であったと報告されている29.30)。また， PMMA の立体規則性も影響し，シンジオタクチック，ア タクチック PMMA は相溶, イソタクチック PMMA は低

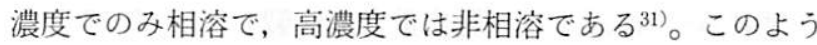
に相溶性は作製条件等に大きく依存する。

また， 2 成分系では非相溶であるが第 3 成分の添加で相 溶になる場合もある。PMMA と PVAc は, 表 1 で著者ら が確認したように非相溶である。Pinoit ら ${ }^{32)}$ はポリエピク ロロヒドリン, $\mathrm{Hsu}^{33)}$ は PVPh をそれぞれ第 3 成分とす ることで相溶系にしている。いずれも第 3 成分と PMMA あるいはPVAc との間に相互作用が発現することを確認 している。非相溶系では, PVC/PVA ブレンドに第 3 成 分として PMMA を加えると, 分散サイズが著しく微細化 することを著者ら ${ }^{4)}$ が明らかにしている。

相溶性の判定方法も重要である。図 1 には, ポリマーブ レンド系の動的粘弾性測定による損失弾性率 $\left(E^{\prime \prime}\right)$ のピー

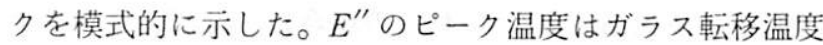
$\left(T_{\mathrm{g}}\right)$ に依存する。成分単独のピークが (a) のように出現 する系で，ブレンド後むほぼ同じ温度にピークが別々に明 確に出現すると非相溶系とみなされる。これに対して (b)

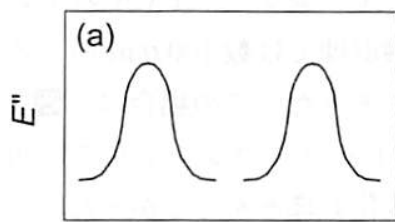

温度

(c)

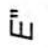

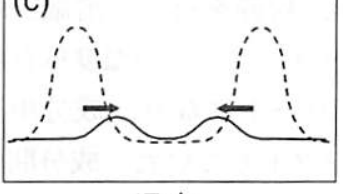

温度

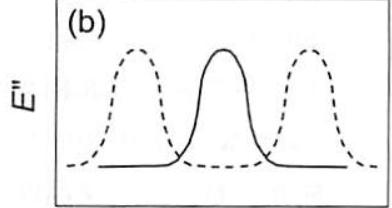

温度

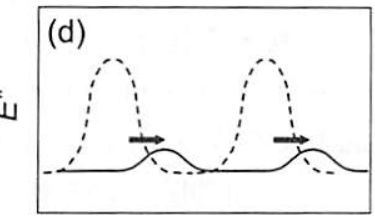

温度
図 1 ポリマーブレンドの相溶性と動的粘弾性測定による 損失弾性率 $\left(E^{\prime \prime}\right)$ の温度依存性。a: 成分単独あるい は非相溶系, b: 相溶系, c: 成分間相互作用が働く非 相溶系, d: PMMA/PVA ブレンド (非相溶系) の場合 


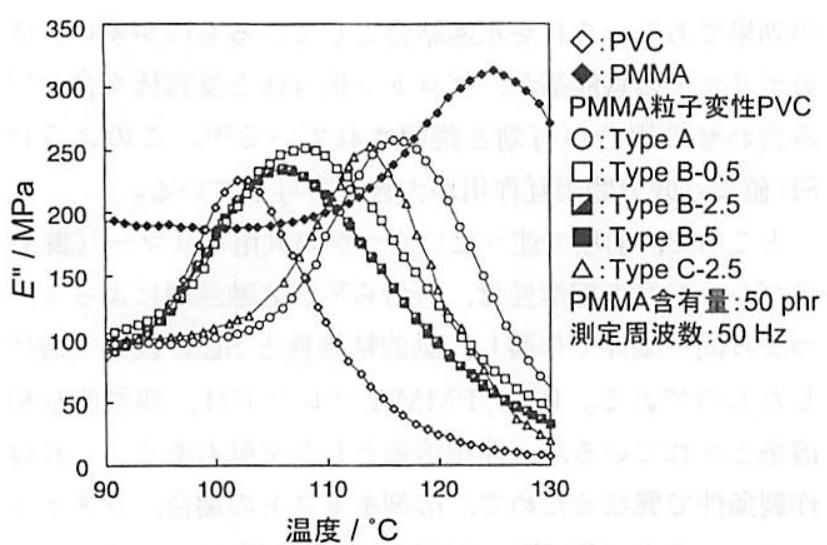

図 $2 \mathrm{PVC} / \mathrm{PMMA}$ ブレンドの動的粘弾性測定による 損失弾性率 $\left(E^{\prime \prime}\right)$ の温度依存性

のように両者の中間の温度に単一のピークが出現する場合 は，相溶系と判断される。

著者ら ${ }^{2,3)}$ は，シード乳化重合で作製したサブミクロン サイズの PMMA 粒子を凍結乾燥で粉末状にし，これを PVC と溶融混練する方法で PVC/PMMA ブレンドを作 製した。 $E^{\prime \prime}$ の測定結果を図 2 に示した。PVC $(\diamond)$ およ び PMMA 単独 (๖)のピークはそれぞれ約 $100^{\circ} \mathrm{C}$, 約 $125^{\circ} \mathrm{C}$ で，ブレンド系 $(\bigcirc)$ はこれらの中間に単一のピークが出 現していた。SEM 観察からも相溶系であることを確認し た。同時に，橋架け点を導入した粒子によるブレンドも作 製した。上述の Type A は橋架け点を含まない PMMA 粒 子で, Type Bおよび C はこれを含む。シード乳化重合過 程での橋架けモノマーの添加時期の違いで, Type B は粒 子表面層に橋架け点が多く分布し, Type C は逆に粒子内 部に多く分布する。 $\mathrm{B}, \mathrm{C}$ の後の数字は橋架けモノマーの

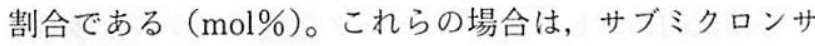
イズの橋架け PMMA 粒子がドメインとして分散していた

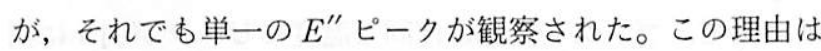
現在検討中であるが，ポリマーブレンドの定石とされてい る見方も例外のあることは知っておくべきである。

なお，既報 ${ }^{4)}$ での PVC/PVA ブレンド（PVAのケン 化度 $98 \mathrm{~mol} \%$ ）は，通常の溶融混練では数 $100 \mu \mathrm{m}$ のドメ インサイズで完全な非相溶系であった。この場合は, 図 1 - $\mathrm{a}$ のような成分単独の 2 つのピークがブレンド系であ明 確に観察され，ピーク温度の变化むほとんどなかった。こ れに対してPVAの水溶液をあらかじめ作製し，これに PVC 粉末を混合してから乾燥, 粉砕を行って溶融混練し た場合は，数 $\mu \mathrm{m}$ のドメインサイズで $E^{\prime \prime}$ の温度依存性は 図1-cのように両ピークがブロードになり，成分単独の ピークの中間寄りにそれぞれシフトしていた。成分間の相 互作用が発現した効果と判断している。

異種ポリマーの混合レベルを高分解能固体 NMR の緩 和時間から求めた研究がある ${ }^{14,34)}$ 。核スピンの緩和時間が 隣接する分子との相互作用に影響されることから, 分散レ
ベルを次式より算出している(14)。

$$
L=\left[6 D T_{\mathrm{i}}(\mathrm{H})\right]^{1 / 2}
$$

$L$ は最大有効拡散距離といわれ, 異種ポリマー分子間の距 離に相当する。 $D$ はスピン拡散係数, $T_{\mathrm{i}}(\mathrm{H})$ は測定された 緩和時間である。Lau ら ${ }^{14)}$ は, PVC/PMMA ブレンドの 混合レベルを $18-20 \AA$ としている。これは相溶系であるこ とを意味している。Sankarapandian ら ${ }^{34)}$ は, 同様の検 討で PVC/ポリメタクリル酸フェニルブレンドの混合レベ ルが 3-15 nm であるとしている。相溶系であることの確 認には有効な手法と思うが，いずれも算出された数值を混 合レベルとして明記している。著者は,この関係を検証し た論文をまだ見つけていないのでこの数值が意味のあるむ のか疑問である。

\section{4. 成分間相互作用はどこまで見えるのか？}

フーリエ变換赤外分光分析 (FT-IR) によるのが一般 的だが，ポリマーブレンド系であるがゆえの問題む多い。 PVC/PMMA 系は, 成分間相互作用により相溶する。 Dompas ら ${ }^{35)}$ は, メタクリル酸メチルースチレン共重合 体を PVCとブレンドし，スチレン含有量が増加すると相 溶から非相溶に变化することで PVC-PMMA 分子間の効 果を明らかにしている。

著者ら ${ }^{5)}$ は, PVC/PMMA ブレンドの低分子モデル物 質として 1,3-ジクロロブタンとメチルイソブチレートを 用い, 混合系の FT-IR を測定した結果, メチルイソブチ レートのカルボニル基に基づく $1760 \mathrm{~cm}^{-1}$ 付近のピークは $1740 \mathrm{~cm}^{-1}$ 付近に明確にシフトしていた。ところが, 実際 の PVC/PMMA 系では PMMA のカルボニル基に基づく $1730 \mathrm{~cm}^{-1}$ 付近のピークは, ブレンドにより低波数側と高 波数側への 2 つシフトが見られ，シフト量む小さかった。 これは PMMA の分子内相互作用がブレンドにより緩和さ れたあのと，これが新たに PVC との分子間相互作用を形 成したものの 2 種類が存在していることを示している。こ のようにポリマーブレンド系では, 明確なシフトが得られ ない場合が多い。

図 3 には, Fan ら ${ }^{28)}$ によるポリアクリル酸（PAA）と ラクトース（a）あるいはポリオール（b)とのブレンドで, PAA のカルボニル基のシフトを FT-IR で観察した結果 を示した。いずれもブレンドにより高波数側にシフトして いた。彼らは, PAAの分子内水素結合の方が PAA とラ クトースあるいはポリオールとの成分間相互作用より強い ためと説明している。このように成分間相互作用により一 般の概念と逆方向へのシフトもあることは興味深い。彼ら はヒドロキシ基に基づく $3100 \sim 3400 \mathrm{~cm}^{-1}$ 付近のブロード なピークの解析も行い（図 4), 両方のデータから総合的 に判断してこのような結論を導いている。詳細は彼らの報 


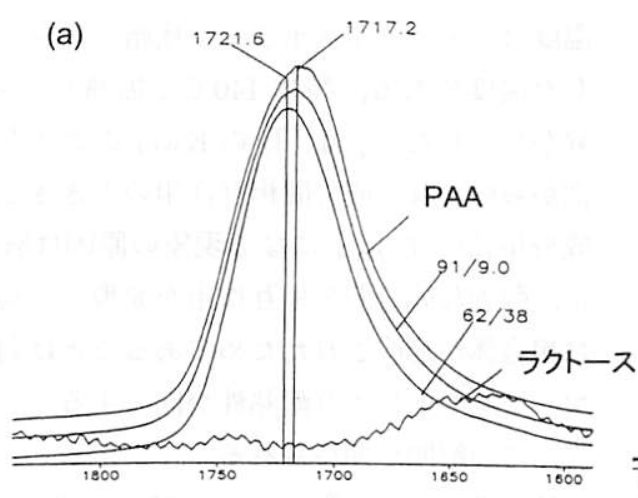

波数 $/ \mathrm{cm}^{-1}$

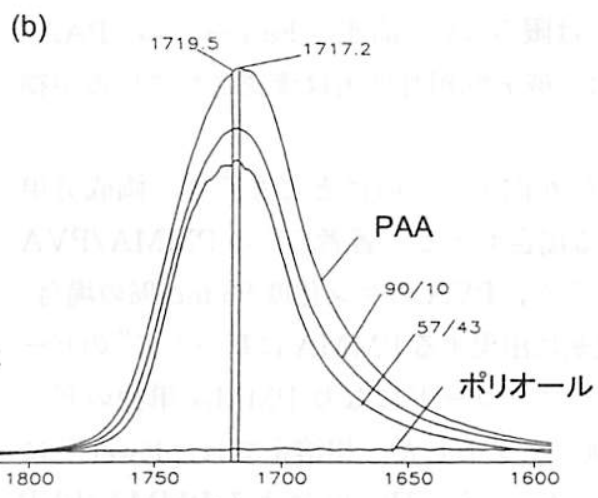

波数 $/ \mathrm{cm}^{-1}$

図 3 PAA/ラクトース (a) およびPAA/ポリオールプレンド (b) の FT-IR スペクトル $\left(1600-1800 \mathrm{~cm}^{-1}\right)$

(a)

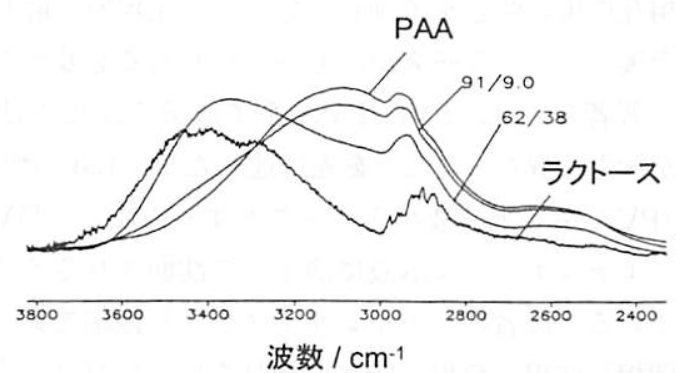

(b)

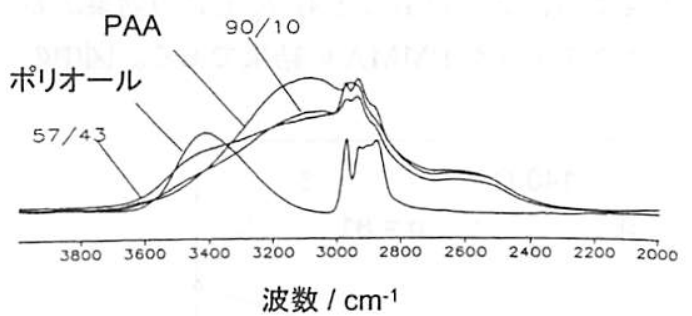

(b) の FT-IR スペクトル $\left(2000-3800 \mathrm{~cm}^{-1}\right)$
告を参照して頂きたいが，ポリマーブレンドの FT-IR で は複雑なデータから正確な判断が求められる。

Gordon ら ${ }^{36)}$ は, ポリ乳酸 (PLA) とポリヒドロキシ エステルエーテル（PHEE）ブレンドを行った。PLA と PHEE のカルボニル基は近い波数に出現するので, ブレ ンド系での区別は困難である。そこで波形分離を行って分 子間水素結合を明らかにしている。ただし，これができる のはバックデータの蓄積があって正確に波形分離できる系 に限られる。

\section{5. 成分間相互作用で物性は向上するのか？}

著者ら ${ }^{2,3)}$ は, PVC/PMMA 系で組成を振って動的粘弾

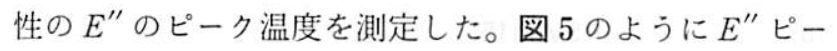
ク温度の実測値 $(\bigcirc)$ を PVC と PMMA 単独のピーク值 (ガラス転移温度, $T_{\mathrm{g}}$ に相当する) の加成則から算出した 値 (○) と比較した。加成則は下記の Fox 式 ${ }^{37}$.38) を用いた。

$$
\frac{1}{T_{\mathrm{g}}}=\frac{W_{1}}{T_{\mathrm{g} 1}}+\frac{W_{2}}{T_{\mathrm{g} 2}}
$$

ここで $T_{\mathrm{g} 1}, T_{\mathrm{g} 2}$ はそれぞれ成分 1,2 の $T_{\mathrm{g}}, W_{1}, W_{2}$ は成分 1, 2 の重量分率である。

その結果, 実測值の方が高く, 混合比 $1 / 1$ 付近で実測 值と加成則の差が最む大きかった。これは成分間相互作用 形成, つまり上述の水素結合の効果である。このように成 分間相互作用の形成で物性が向上するというのは一般的な

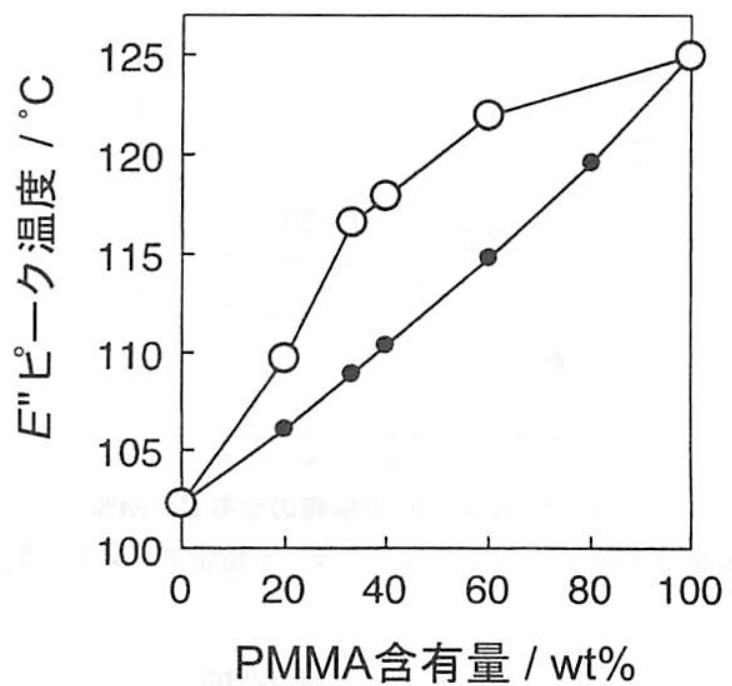

図 5 PVC/PMMA ブレンドの動的粘弾性測定による 損失弾性率 $\left(E^{\prime \prime}\right)$ のピーク温度。 $\bigcirc$ : 実測値,

○: 加成則 (Fox 式) による計算値

考え方で，Kwei ${ }^{18)}$ は，加成則に成分間相互作用の項を加 えた下記の Kwei 式を提案している。

$$
T_{\mathrm{g}}=W_{1} T_{\mathrm{g} 1}+W_{2} T_{\mathrm{g} 2}+q W_{1} W_{2}
$$

記号は（7）式と同じであるが, $q$ は成分間相互作用の大き さを表す。

しかしながら，物性が向上した系は成分間相互作用の効 果に間違いないが, 成分間相互作用が形成しても必ずしも 
物性が向上するとは限らない。前述の Fan ら ${ }^{28)}$ の, PAA/ ラクトース系では，成分間相互作用は確認されているが物 性の向上はない。

加成則以上に $T_{\mathrm{g}}$ が向上するのにとどまらず，両成分単 独の $T_{\mathrm{g}}$ 以上になる場合むある。著者ら ${ }^{5)}$ の PMMA/PVA 系は非相溶系であるが, PVAのケン化度 $98 \mathrm{~mol} \%$ の場合, 動的粘弾性の高温側に出現する PMMA に基づく $E^{\prime \prime}$ のピー クは図 1-d のようにブロードになり PMMA 単独のピー ク温度より高温側にシフトした。相溶系では, Kwei ${ }^{18)} に$

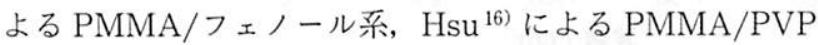
系, Kuo ら ${ }^{23)}$ による $\mathrm{PBPh} / \mathrm{PVP}$ 系がブレンドで両成分 の $T_{\mathrm{g}}$ を超えることが報告されている。

図 6 には, Kwei ${ }^{18)}$ による PMMA/フェノールノボラッ ク樹脂系の結果を示した。彼らはPMMA の立体規則性の 影響も検討しており，これはもっとも $T_{\mathrm{g}}$ 上昇の効果が高 かったシンジオタクチック PMMAの結果である。四中の

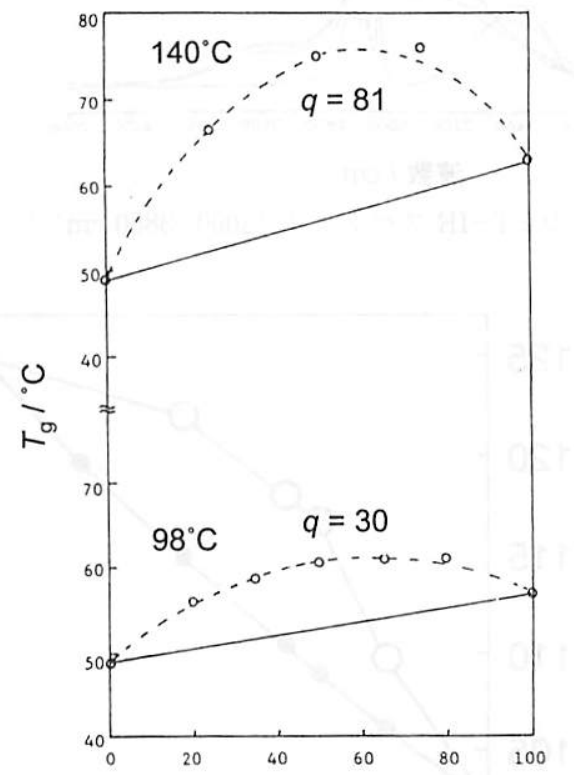

フェノールノボラック樹脂の含有量 / wt \%

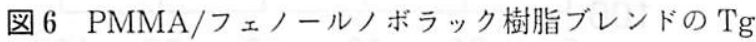

(a)

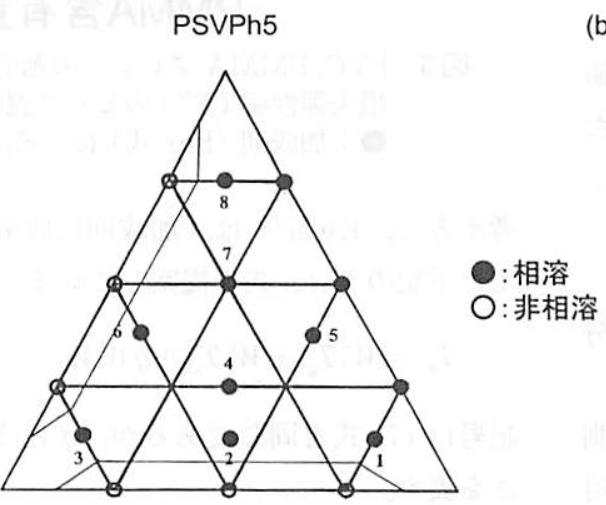

PEMA

PMMA
温度はフェノールノボラック樹脂のみをブレンド前に加熱 した温度である。特に $140^{\circ} \mathrm{C} て ゙$ 加熱した場合に高い $T_{\mathrm{g}}$ 上 昇が見られた。 $q$ は (8) の Kwei 式より求めており, 加成 則からのずれで成分間相互作用の大きさを判断している。 成分単独の $T_{\mathrm{g}}$ 以上になる現象の原因は解明されていない が, 強固な成分間の相互作用が発現し, 易動性の低い剛直 な複合体が形成されたためであることは間違いない。ポリ マーブレンドにより耐熱性が向上することは魅力であるの でこの解明が期待される。

Hartikainen ら ${ }^{39)}$ は，ポリアミド 66/フェノール樹脂才 リゴマーブレンドについて，FT-IR で成分間相互作用を 検討するととむに低分子モデル化合物の分子モデリングよ 分子軌道法による計算で静電ポテンシャルを求め, 成分間 相互作用の強さを予測している。上記現象の解明のために 今後このような研究が，もっ上行われる必要がある。

著者ら ${ }^{4)}$ は, PVC/PVA 系で成分の添加方法で分散性 が大きく異なったことを先に述べたが, Lai ら ${ }^{40)}$ も, PEO /PVA 系で水溶液からキャストする方法と, DMF 溶液を ジェチルエーテル溶液に滴下して沈殿させる方法を比較し ている。後者のドメインサイズがより微細であった。成分 間相互作用の発現可能な官能基をいかに有効に会合させる かの課題の解明も今後の重要な課題である。

上述の著者ら ${ }^{5)}$ の PMMA/PVA 系は, 成分単独以上の $T_{\mathrm{g}}$ 以上となり, FT-IR による PMMAのカルボニル基の ピークも明確に低波数側にシフトしていた。この点, 上述 の PVC/PMMA 系と異なっていた。つまり, 成分間相互 作用は確実に PVC/PMMA 系より大きいはずである。し かしながら, 成形物は融着が不十分な“粟おこし”状であっ た。これはこの系の成分間相互作用が強すぎることを示唆 している。

$\mathrm{Hsu}^{41)}$ は, 非相溶の PMMA とポリメタクリル酸エチ ル (PEMA) 系にスチレンービニルフェノール共重合体 (PSVPh) を第 3 成分として加えると相溶することを明ら かにしている。図 7 にその結果を示した。PSVPh 中の

(b)

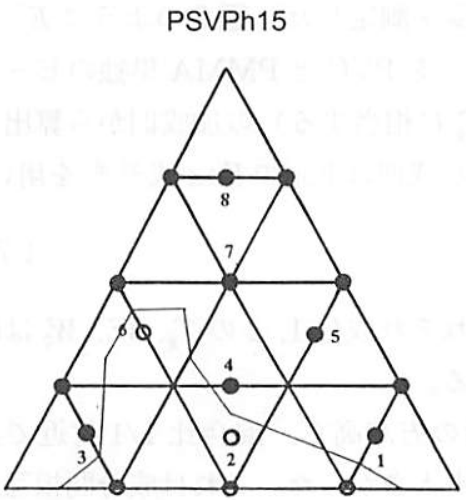

PEMA

PMMA

図 7 PMMA/PEMA/PSVPh ブレンドの相溶性 
$\mathrm{VPh}$ の共重合比が 5 と $15 \mathrm{~mol} \%$ のあを用いている。そ れぞれ PSVPh5, PSVPh15 と記している。PSVPh5 では PEMA と相溶しないが, PSVPh15 では相溶となる。と ころが 3 成分系では (a)の PSVPh5 より (b) の PSVPh15 の方が相溶しない組成域（○）がより広い。彼はPSVPh との成分間の相互. 作用が PEMA より PMMA との方がよ り強いためであると推定している。

これらの 2 つ例は，ポリマーブレンドの成分間の相互 作用にも“過ぎたるは及ばざるが如し”があることを示し ている。

\section{6. おわりに}

ポリマーブレンドに関するいくつかの文献を見てきたが, 各論はかなりやり尽くされた感がある。成分間相互作用の 見極めと，いかに有効な官能基の会合を起こさせるかにつ いての考え方が残された重要な課題上著者は考えている。 著者らむこの解明のために今後も努力したい。本稿がポリ マーブレンドの発展に何らかの寄与することがあれば幸甚 である。

\section{文献}

1) Y. Nakamura, H. Tabata, H. Suzuki, K. Iko, M. Okubo, and T. Matsumoto, J. Appl. Polym. Sci., 32, 4865 (1986)., 33, 885 (1987).

2) Y.Nakamura, M.Kanbe, E.Takekuni, and T.Iida, Colloid Polym. Sci., 279, 368 (2001).

3) Y. Nakamura, M. Kanbe, E. Takekuni, and T. Iida, Composite Interfaces, 8, 367 (2001).

4） 中村吉伸, 竹内一眞, 釜口章弘, 鍋田宗明, 飯田健郎, 日本 接着学会誌, 43, 43 (2007).

5） 中村吉伸, 竹内一呉, 鍋田宗明, 仮屋瑛二, 飯田健郎, 日本 接着学会誌, 43, 230 (2007).

6) J. H. Hildebrand, J. Amer. Chem. Soc., 51, 66 (1929).

7) J. Brandrup, and E. H. Immergut (Ed.), "Polymer Handbook (Third Edition)", John Wiley \& Sons, Inc., (1989).

8）中村吉伸他, 未発表.

9）栗原福次, “高分子材料大百科”, 日刊工業新聞社, 1999.

10) P. J. Flory, J. Chem. Phys., 10, 51 (1942).

11) M. L. Huggins, Ann. N. Y. Acad. Sci., 43, 1 (1942).

12) P. A. Small, J. Appl. Chem., 3, 71 (1953).

13) R. F. Fedors, Polym. Eng. Sci., 14, 147 (1974).

14) C. Lau, and Y. Mi, J. Polym. Sci, Part B: Polym. Phys., 39, 2390 (2001).
15) N. Belhaneche-Bensemra, A. Bedda, and B. Belaabed, Macromol. Symp., 202, 151 (2003)

16) W.-P. Hsu, J. Appl. Polym. Sci., 81, 3190 (2001).

17) S. Zhang, and J. Runt, J. Polym. Sci., Part B, Polym. Physics, 42, 3405 (2004).

18) T.K.Kwei, J. Polym. Sci., Polym. Lett. Ed., 22, 307 (1984).

19) T. R. Lutz, Y. He, M. D. Ediger, H. Cao, G. Lin, and A. A. Jones, Macromolecules, 36, 1724 (2003).

20) S. N. Cassu, and M. I. Felisberti, Polymer, 38, 3907 (1997).

21) J.M.G.Cowie, I.McEwan, I.J.McEwen, and R.A.Pethrick, Macromolecules, 34, 7071 (2001).

22) G. Polacco, M. G. Cascone, L. Petarca, A. Peretti, Eur. Polym. J., 36, 2541 (2000).

23) S. W. Kuo, and F. C. Chang, Macromolecules, 34, 7737 (2001).

24) S. W. Kuo and F. C. Chang, Macromolecules, 34, 5224 (2001).

25) R. Sh. Vartapetian, E. V. Khozina, D. Geschke, F. Rittig, M. M. Feldstein, A. E. Chalykh, Macromol. Chem. Phys., 202, 2648 (2001).

26) S.-W. Kuo, and F.-C. Chang, Macromol. Chem. Phys., 202, 3112 (2001).

27) L.-T. Lee, and E.-M. Woo, Polym. Int., 53, 1813 (2004).

28) X.-D. Fan, Y.-L. Hsieh, J. M. Krochta, and M. J. Kurth, J. Appl. Polym. Sci., 82, 1921 (2001).

29) W. Li, L. Shi, D. Shen, and J. Zheng, Polym. Int., 27, 57 (1992).

30) G. Kögler, and P. A. Mirau, Macromolecules, 25, 598 (1992).

31) E. J. Vorenkamp, G. ten Brinke, J. G. Meijer, H. Jager, and G. Challa, Polymer, 26, 1725 (1985).

32) D. Pinoit, R. E. Prud'homme, Polymer, 43, 2321 (2002).

33) W.-P. Hsu, J. Appl. Polym. Sci., 92, 2797 (2004).

34) M. Sankarapandian, and K. Kishore, Polymer, 37, 2957 (1996).

35) D. Dompas, G. Groeninckx, M. Isogawa, T. Hasegawa, and M. Kadokura, Polymer, 38, 421 (1997).

36) S. H. Gordon, X. Cao, A. Mohamed, and J. L. Willett, J. Appl. Polym. Sci., 97, 813 (2005).

37) T. G. Fox, Bull. Am. Phys. Soc., 1, 123 (1956).

38) H. Y. Chen, E. V. Stepanov, S. P. Chum, A. Hiltner, and E. Baer, J. Polym. Sci., Part B Polym. Phys., 37, 2373 (1999).

39) J. Hartikainen, O. Lehtonen, T. Harmia, M. Lindner, S. Valkama, J.Ruokolainen, and K. Friedrich, Chem. Mater., 16, 3032 (2004).

40) W.-C. Lai, and W.-B. Liau, J. Appl. Polym. Sci., 92, 1562 (2004).

41) W.-P. Hsu, J. Appl. Polym. Sci., 89, 2088 (2003). 